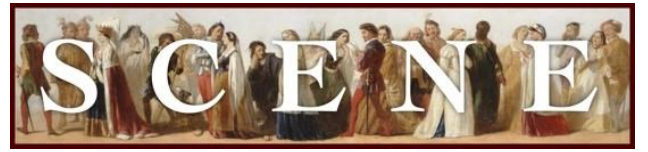

\title{
Why They Are So Sad in Merchant of Venice
}

\author{
by Erin Kelly. Written on 2017-08-10. Published in 2017 Issue 2.
}

For the production: The Merchant of Venice (2017, Bard on the Beach, Canada). See production details at the end of the review.

Even AS CRitics CONTINUE TO DEBATE WHETHER SHAKESPEARE'S MERCHANT OF VENICE IS anti-Semitic or is a play that exposes, analyzes, and perhaps critiques anti-Semitism, the recent Bard on the Beach production takes a strong position - choosing to call attention not just the play's moments of anti-Semitism but also its sexism, racism, and classism. The result was a compelling exploration of how tragedy can result from disempowered people striving for (and perhaps even getting) what they have been told by a dominant culture that they should want. Rather than allowing the play to seem a reflection of an earlier (and comfortingly distant) period's prejudices, Nigel Shawn Williams utilizes a present-day setting in ways that call attention to our own cultural moment's moral ugliness.

Most obviously, the treatment of Shylock (played by Warren Kimmel) makes explicit both why he hates Antonio and the other Christians and the reasons he ultimately decides to demand debt repayment in the form of a pound of flesh. This production's Shylock first appears as a businessman in a somber, well-tailored suit - his Jewish identity signaled only by a modest yarmulke - walking purposefully across the stage until he is tripped deliberately by Antonio (played by Edward Foy). Here Shylock is a dignified figure who refuses to engage with his attacker; he later remains composed even as Antonio expresses vehement hate for him while requiring (indeed, demanding) a loan. The Jewish moneylender even seems generous towards his departing servant Lancelet (Andrew Cownden), writing him a check that is either a gift or a final salary payment while pointing out that the young man is leaving him to follow an impoverished master in Bassanio (Charlie Gallant). It is only after he discovers that his daughter Jessica (Carmela Sison) has eloped with a Christian that Shylock becomes enraged and he seems quite justified in doing so because he retrospectively realizes that he spotted the disguised Jessica being carried off on the shoulders of howling party-boys. He is clearly wounded when his friend Tubal (Paul Moniz de Sa in Hasidic dress) shows him a cellphone photo of the ring (given to Shylock by his presumably deceased wife) that Jessica traded for a monkey. 
Shylock's steadfast determination to have his bond in the trial scene therefore seems understandable - if horrific. He acts less like the controlled gentleman and more like the wild Christians we have witnessed behaving badly up to this point in the performance as he angrily demands revenge through fulfillment of the law. His perspective on the Christians is further bolstered for an audience that has to suffer the Christians seated around Antonio calling Shylock a "dirty Hebe," expressing a wish turn him over to the Gestapo, and taunting him with a Nazi salute. (Notably, this was a scene in which the production in which some performers became conspicuously self-conscious and tentative - the director's vision of how intolerant the citizens of Venice might be seemed impossible for a few of the young Canadian actors to carry out convincingly, much less with enthusiasm.)

Yet Shylock's refusal to extend the sort of mercy that Portia (Olivia Hutt) calls for is his undoing; the moment he becomes the blood-thirsty monster the Christians' anti-Semitism imagines him to be, Shylock exposes himself as a "stranger" in Venice. As that "stranger," he is vulnerable to losing his property, life, and religion - in ways the Christian citizen Antonio will never be. Portia in this production appears to recognize the full implications of what could be the aftermath of her commentary on the bond as her silent reading and rereading and rereading of the document onstage stretches into several uncomfortable minutes. She delivers her reading of the law cautiously and with some reticence. Separated physically from Antonio's table of supporters, who howl with delight at her wisdom, she derives no satisfaction from the way the law turns against Shylock, immediately recognizing that Antonio's demand for the Jew to convert is cruelty rather than comfort.

Certainly, Portia is not significantly more happy in the final scene of the play than is Shylock. The production makes explicit through judicious cutting and performance choices that Portia wishes to be a good wife to the very handsome Bassanio when her husband. (This desire does not mitigate for the audience, however, her chilliness to other suitors, nor her outright racist comments about the Prince of Morocco. Portia in this director's eyes is sympathetic but flawed.) The trial scene opens her eyes to the corruption of Venetian society - her husband's beloved friend is cruel, and Bassanio is suspiciously intimate with the fashionable women he embraces when Antonio is freed from Shylock's bond. Portia's faith in her husband seems irredeemably shattered after he turns over to the skillful young judge, Portia in disguise, the ring his wife gave to him that he swore never to give away. Rather than a joyful reunion and the revelation of an innocent bit of duplicity, then, the final scene stresses Portia and Nerissa's pain at their husbands' betrayal and makes the audience feel keenly that any future relationship would require the men to heal a significant breach of trust. Portia in particular seems early in the production to be unkind mostly because she is sheltered and idealistic. Events in Venice open 
her eyes to the profound immorality of the world outside of Belmont and then to the full realization that she has aligned herself permanently with a corrupt patriarchal society through marriage the man she wanted to choose her.

The play's other romantic union offers even less hope for contentment. Jessica makes herself vulnerable to a Lorenzo (Chirag Naik) who clearly finds her fortune at least as attractive as her person. During the scene when she flees her father's house, he pays a bit more attention to the treasure she throws down than to Jessica's well-being. By the time they are in Belmont "on a night such as this," Lorenzo is as disgusted with her as she is with him - having apparently run through all of their money, they deliberately seek to wound one another with their references to doomed couples. Even the final scene's news that Shylock's wealth will now be theirs cannot mend the rift. By seeking romance, Jessica has made herself as miserable as Lorenzo has by acting the part of seducer.

Even Antonio ends the play as a tragic if never fully sympathetic figure. The audience learns to question his morals as early scenes show him drinking to excess, throwing payment of a restaurant bill onto the ground for a beleaguered waiter to retrieve, and assaulting Shylock both verbally and physically. In the trial scene, convinced that he is going to die, he does reveal some motivation for his exaggerated machismo (not to mention his particular devotion to a young male friend) by kissing Bassanio fully and lingeringly on the mouth, an act of passion that generates silent reactions ranging from befuddlement (on the part of Bassanio) to horror (from many of his other companions). Yet the play seems to reveal that Antonio's suffering is largely self-inflicted through his apparent refusal to reveal his true feelings - and his quiet melancholy as he finds himself unpartnered in the play's closing moments cannot excuse the suffering he causes others.

The Venice that Nigel Shawn Williams creates is dominated by fashionable, glittering, and selfish people - Antonio, Bassanio, Gratiano, Saleria (a female Salerio), Solania (a female Solanio), and others - who damage anyone weaker than themselves unfortunate enough to cross their paths - including Shylock, Jessica, and even Portia and Nerissa. Characters like Antonio and Bassanio are not happy or fulfilled at the end of the play, but the production suggests that they are perhaps better off financially and socially than they were at its beginning. However, they have made Portia, Shylock, and other more vulnerable people miserable.

The production begins by turning Antonio's opening speech into a chorus spoken by all the Christian Venetian characters before reprising it as a personal expression: "I do not know why I am so sad." Williams directs Merchant of Venice so that the entire play is sad, and the audience leaves with a strong sense that callous intolerance of and indifference to others is the reason for 
this pervasive downheartedness. No comic ending is possible in Venice - or in the Belmont that has been infiltrated by Venetian merchants.

\section{Production Details}

\section{General}

Title

Year

Theater Company

Theaters

\section{Cast}

SHYLOCK
ANTONIO
BASSANIO
PORTIA
NERISSA
DUKE OF VENICE
PRINCE OF MOROCC
PRINCE OF ARAGON
SOLANIA
GRATIANO
SALERIO
LORENZO
JESSICA
TUBAL
LAUNCELOT GOBBO
LEONARDA
BALTHASAR
MESSENGER
BEATRICE

\section{Creatives}

Director
Directing Apprentice
Costume Designer
Scenic Designer
Lighting Designer
Sound Designer

The Merchant of Venice

2017

Bard on the Beach

Douglas Campbell Studio Stage (Canada)
WARREN KIMMEL
EDWARD FOY
CHARLIE GALLANT
WARREN KIMMEL
LUISA JOJIC
EDWARD FOY
Charlie Gallant
Olivia HutT
LUISA JOJIC
KAMYAR PazANDEH
ADELE NORONHA
ChIRAg NAIK
NADEem Phillip
NADEEM Phillip
ANDREW COWNDEN
PAUl MONIZ DE SÀ
Kate Besworth
CHIRAG NAIK
KAMYAR PAZANDEH

\author{
Nigel ShaWn Williams \\ Paul Moniz de Sà \\ DREW FACEY \\ ADELE NORONHA \\ ADRIAN MUIR \\ CARMELA SISON
}




$\begin{array}{ll}\text { Fight Director } & \text { Joshua Reynolds } \\ \text { Stage Manager } & \text { Joanne P.B. Smith } \\ \text { Assistant Stage Manager } & \text { Ruth Bruhn } \\ \text { Apprentice Stage Manager } & \text { Jennifer Stewart } \\ \text { Head Voice \& Text Coach } & \text { Alison Matthews } \\ \text { Projection Designer } & \text { Chirag Naik }\end{array}$

